УДК: 336.717.061:330.3

DOI: https://doi.org/10.37320/2415-3583/16.14

Калита О.В.

кандидат економічних наук, старший викладач

Київський національний торговельно-економічний університет ORCID: https://orcid.org/0000-0003-2020-5751

Сундук Т.Ф.

асистент

Київський національний торговельно-економічний університет ORCID: https://orcid.org/ 0000-0001-8433-1939

\title{
СТРАТЕГІЧНІ НАПРЯМИ РЕФОРМУВАННЯ РИНКУ КРЕДИТНИХ ПОСЛУГ В УКРАЇНІ В КОНТЕКСТІ СВРОІНТЕГРАЦІЙНИХ ПРОЦЕСІВ
}

\begin{abstract}
Статтю присвячено дослідженню теоретичних засад та практичних рекомендацій стратегічного реформування ринку кредитних послуг Украӥни в умовах євроінтеграції. Досліджено сутність інформаџійно-кредитного ринку, який відображає специфічні економічні відносини між власниками $і$ користувачами інформаційних ресурсів і послуг, щьо опосередковують їх обмін, купівлю-продаж у рамках кредитної системи. Виявлено, щзо інформаційно-кредитний ринок України в умовах євроінтеграиії розвивається иляхом універсалізації, тобто одні й ті ж самі учасники ринку пропонують усе більш різноманітні банківські продукти. Доведено, щзо відсутність єдиного органу лічензування та управління, щео діє за стандартними правилами, може призвести до підвищених витрат суб'єктів державного регулювання під час реформування ринку кредитних послуг
\end{abstract} в Україні.

Ключові слова: кредитні послуги, інформаційно-кредитний ринок, бюро кредитних історій, суб'єкти кредитного ринку, Національний банк України.

Постановка проблеми. Кредитування як основа банківського бізнесу - найдинамічніший сектор ринку банківських послуг в Україні. Його функціонування виявило безліч проблем, які стають перешкодою для збільшення обсягу наданих кредитних послуг. До них належать кредитні ризики, недостовірність інформації про клієнтів банку, складності з налагодженням роботи зі стандартизованими інформаційними продуктами. 3 урахуванням цих проблем важливу роль починають відігравати чинники, пов'язані $з$ необхідністю реформування ринку кредитних послуг в Україні в контексті євроінтеграційних процесів.

Реформування ринку кредитних послуг в Україні пов'язане 3 необхідністю побудови, функціонування і розвитку інфраструктури кредитного ринку. Інфраструктура кредитного ринку повинна являти собою сукупність або систему компетентних установ (банки, кредитні спілки, колектори та ін.) і взаємозв'язку між ними, покликаних обслуговувати відносини між кредитором і позичальником. Дана інфраструктура і взаємовідношення учасників повинні будуватися на ринкових принципах, причому товаром виступатимуть не лише кредитні продукти, а й інформація, необхідна для забезпечення цих відносин.

Аналіз останніх досліджень і публікацій. Дослідженню проблем функціонування і розвитку ринку кредитних послуг присвячено безліч наукових доробків провідних вітчизняних і зарубіжних економістів та учених, серед яких: О. Васюренко, О. Вовчак, А. Ган, Б. Івасів, О. Заруба, М. Кері, О. Кириченко, 3. Ковальова, Л. Кузнєцова, В. Лагутін, Б. Луців, І. Лютий, Г. Маклеод, Т. Майорова, В. Міщенко, О. Морозова, Л. Павлова, Л. Примостка, Б. Пшик, Д. Рікардо, М. Римар, Н. Рогожнікова, М. Савлук, Р. Слав’юк, А. Сміт, T. Смовженко, В. Унинець-Ходаківська, А. Чухно, Н. Шелудько, Й. Шумпетер та ін.
Проте, незважаючи на теоретичну важливість та практичну вартість таких робіт, в українській науковій та економічній літературі відсутні стратегічні напрями реформування ринку кредитних послуг в Україні 3 погляду його впливу на подальшу євроінтеграцію.

Мета статті полягає у розробленні теоретико-методологічних основ, науково-методичних підходів та практичних рекомендацій щодо реформування ринку кредитних послуг в Україні в умовах євроінтеграції.

Виклад основного матеріалу. Стратегічним напрямом реформування кредитних послуг в Україні в умовах євроінтеграції є впровадження на практиці поняття «інформаційно-кредитний ринок». Дефініція «інформаційно-кредитний ринок» відображає специфічні економічні відносини між власниками і користувачами інформаційних ресурсів і послуг, що опосередковують їх обмін, купівлю-продаж у рамках кредитної системи. Межа між зазначеними власниками і користувачами умовна, оскільки на практиці власники одного виду інформації можуть бути користувачами іншого іiі виду.

Продукт інформаційно-кредитного ринку - це інформаційний ресурс або послуга, запропоновані як товар, для забезпечення грошово-кредитних відносин учасників ринку кредитних послуг. Специфіка даного продукту в тому, що його істотна частина має лише споживчу вартість і реалізується на безоплатній основі $[1$, c. 55$]$.

Для успішного розвитку будь-якого ринку, у тому числі інформаційно-кредитного, важливо сформувати:

- професійну систему регулювання, що забезпечує функціонування керованих процесів у рамках заданих параметрів;

- механізм контролю - систему спостережень і перевірки відповідності процесу функціонування керованого об'єкта прийнятим управлінським рішен- 
ням, виявлення результатів управлінських впливів на керований об'єкт;

- об'єктивний нагляд - орган зі спостереження.

Ефективність дій регулятора залежить від того, наскільки добре функціонують його організаційні механізми, які повинні забезпечувати інтереси всіх суб'єктів ринку, протидіяти корупції і приватним інтересам, щоб прийняття рішення не можна було звести до волі однієї людини. Окрім того, регулятор повинен сформувати стабільний колектив висококваліфікованих співробітників. Чим вище переконаність учасників ринку в тому, що регулятор діє виключно в інтересах ринку, ефективно захищає їхні права, тим вище ступінь довіри до нього, більше склад учасників і набір реалізованих товарів, швидше розвиваються ринкові інститути.

Поняття «мегарегулятора» зазвичай уживають як поняття моделі об'єднаного або інтегрованого нагляду за фінансовим сектором. За формальними ознаками мегарегулятором стає спеціалізований державний інститут, уповноважений регулювати діяльність більшості фінансових посередників.

Суб'єкти (учасники) інформаційно-кредитного ринку поки чітко не визначені. Велика їх частина регламентована Законом України «Про організацію формування та обігу кредитних історій», інші ж працюють на ринку, не маючи нормативно-правової платформи [6].

Учасників інформаційно-кредитного ринку можна розділити на такі групи:

- установи, що надають кредитні послуги;

- державні політичні та економічні інститути (державні структури, що надають, реалізують або отримують послуги інформаційно-кредитного ринку);

- споживачі кредитних ресурсів, послуг [5, с. 43].

Питання про регулювання діяльності колекторських агентств, кредитних і колекторських спілок, що функціонують на кредитному ринку України, обговорюється давно. Відсутність нормативних документів, що регламентують, видають ліцензії, контролюючи їхню діяльність, $є$ серйозною перешкодою для побудови відносин між ними і рештою учасників ринку в умовах євроінтеграції України. Діяльність колекторських агентств може здійснюватися у формі саморегульованої організації, як і пропонують самі колектори. Однак кращим варіантом $є$ регулювання їхньої діяльності шляхом ліцензування Національним банком України, адже, купуючи у кредитора права вимог до позичальника, колекторське агентство фактично займає місце кредитора, виконує його функції щодо повернення позиченої вартості, що передбачає його обов'язок підкорятися банківському законодавству.

Інформаційно-кредитний ринок України в умовах євроінтеграції розвивається шляхом універсалізації. Одні й ті ж самі учасники ринку пропонують усе більш різноманітні банківські продукти. Наприклад, багато комерційних банків починають пропонувати єдиний пакет послуг, що включає роботу з видачі даних про кредитні історії, роботу з іншими фінансово-кредитними установами (організація «одного вікна»), скорингові послуги, аудит кредитних портфелів та ін.; деякі банки стали використовувати концепцію «фінансового супермаркету» (продаж в одному місці широкого набору послуг). Швидке зростання ринку і поява більш складних і різноманітних продуктів, які пропонують одні й ті ж самі учасники, ускладнюють регулювання їхньої діяльності спеціалізованими державними органами [2, с. 56].

3 іншого боку, структура учасників ринку складна. Вони об'єднуються в конгломерати (кредитні брокери, банки і колектори; банки і страхові компанії і т. п.), що ускладнює роздільний нагляд за їхньою діяльністю. Відсутність єдиного органу ліцензування та управління, що діє за стандартними правилами, може призвести до підвищених витрат суб'єктам державного регулювання.

Виходячи 3 вищевикладеного, можна зробити висновок: мегарегулятор може і повинен бути присутнім на інформаційно-кредитному ринку України. В основі ідеї мегарегулювання цього сегмента ринкової економіки лежить потреба в консолідованому управлінні інформаційними ресурсами і послугами, що сприяє оцінці фінансового становища суб'єктів інформаційно-кредитного ринку, а також необхідність прогнозування і запобігання накопиченню ризиків. Об'єктом діяльності мегарегулятора повинні стати обсяг і структура інформації, що представлена на інформаційно-кредитному ринку. Основний критерій діяльності інформаційно-кредитного ринку - скорочення витрат часу, матеріальних і фінансових ресурсів на пошук і отримання необхідної інформації.

Мегарегулятор повинен виконувати всі функції управління інформаційно-кредитним ринком: моделювання, прогнозування, планування, стратегічне управління, регулювання, моніторинг і контроль.

Регулятор інформаційно-кредитного ринку може застосовувати не лише непрямі методи регулювання (встановлення граничного рівня цін на певні ресурси i послуги, обмеження конкуренції на окремих сектоpax та ін.), а й прямі, тобто приймати на себе витрати 3 підготовки та надання тих інформаційних продуктів і послуг, які є економічно або соціально важливими, але на даному етапі є непривабливими або неможливими для використання комерційними банками.

До першочергових завдань мегарегулятора належать:

- аналіз і чітке визначення для кожного учасника переліку інформаційно-аналітичних завдань, актуальних i перспективних проблем, для вирішення яких необхідно організувати відповідну інформаційно-аналітичну підтримку;

- визначення потреб і відповідальності учасників інформаційно-кредитного ринку (хто, чому і в якому обсязі повинен займатися) в процесах пошуку збору, обробки, зберігання та своєчасного надання фінансової інформації;

- формування цілісної організаційної структури 3 визначенням функціональних і економічних відносин у сфері збору та обробки інформації, розвиток і експлуатація телекомунікаційних систем.

Функціонування інформаційно-кредитного ринку розподілено за часом на три стадії (рис. 1).

Перша стадія включає виявлення потреб в даному виді інформації, можливостей ii надання, розкриття іiі структури й обсягу. На стадії встановлення ціни аналізується попит на інформацію, оцінюється іiі затребуваність, формується ціна за інформацію як на агреговане поняття, що складається не тільки з розміру бажаної 


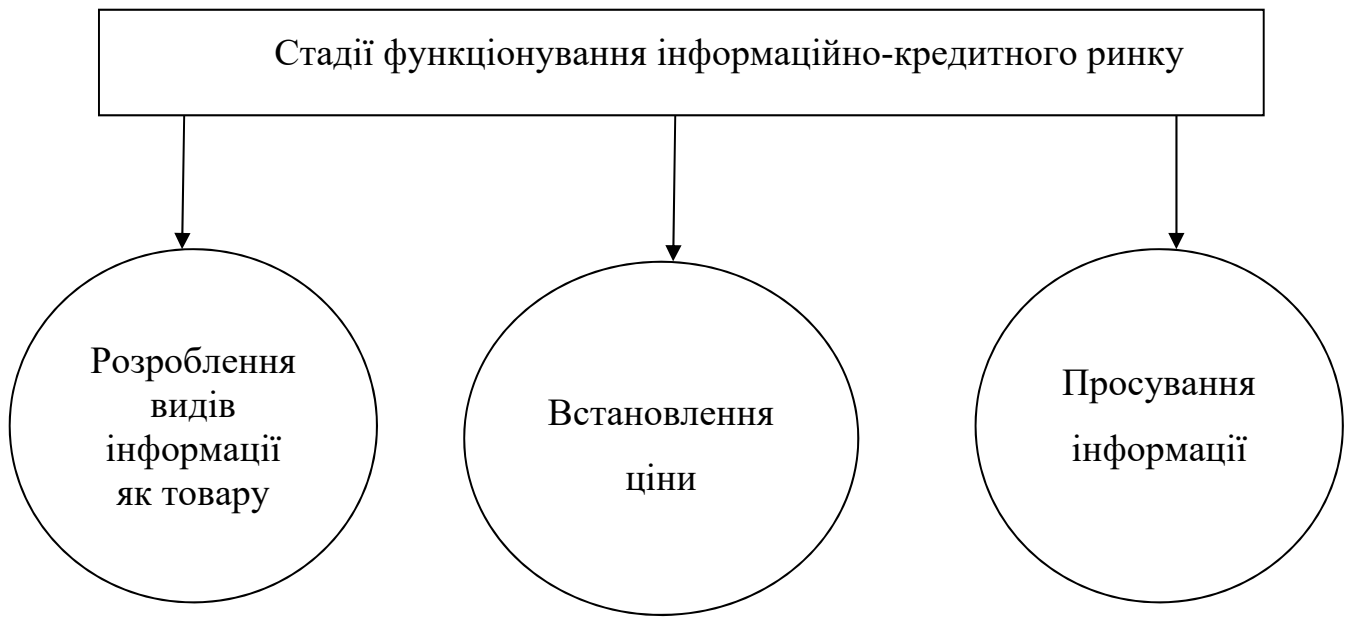

Рисунок 1 - Стадії функціонування інформаційно-кредитного ринку

винагороди і сформованого попиту, а й з умов її збору та надання.

Просування продукту інформаційно-кредитного ринку - розроблення програми (методів) доступу до інформації. Розробляти програму доступу до інформації індивідуально для кожного учасника ринку - процес дорогий, тому необхідною умовою ефективного регулювання є сегментація ринку за видами інформації.

Ефективність виконання завдань, що стоять перед учасниками, багато в чому залежить від поширення інформації про їхню діяльність, формування громадської думки, тобто від управління маркетингом послуг. Таким чином, маркетинг ринку, який базується на інформації про ринок, вплив на попит, сегментацію ринку, маркетинг послуг, - це один 3 організаційнометодичних механізмів регулювання інформаційнокредитного ринку.

За аналогією з ієрархічною системою ринку інформаційних послуг можна побудувати систему інформаційно-кредитного ринку, що складається 3 декількох рівнів: первинні ринкові фактори; суб'єкти ринку; принципи функціонування ринку і ринкові сценарії.

Первинним ринковим фактором, як відомо, $\epsilon$ попит, пропозиція, конкуренція, ціни і тарифи. Суб'єкти ринку володіють такими категоріями, як тип, цілі і функції. Функціонування інформаційно-кредитного ринку грунтується на технологіях інформаційних ринків та покликана:

- гарантувати і регулювати доступ до продуктів інформаційно-кредитного ринку всім зацікавленим особам;

- забезпечувати підтримку (включаючи захист) інформаційних ресурсів в актуальному стані, розширити можливість доступу до них, усувати дублювання інформації;

- відновлювати інформацію в разі її втрати в одного з учасників інформаційно-кредитного ринку;

- забезпечувати розвиток інфраструктури інформаційно-кредитного ринку на основі сумісності стандартів, інтерфейсів і протоколів, єдиних правил надання інформації.

Можливі такі сценарії інформаційно-кредитного ринку:
- конкурентний - конкуренція цін і тарифів або аукціон ресурсів;

- кооперативний - усі власники ресурсів використовують один і той самий механізм для оцінки потреб у ресурсах і переводять свої оцінки у ціни або умови доступу до ресурсів;

- неприбутковий маркетинг - застосування принципів маркетингу до установ та організацій, які не орієнтуються на прибутковість (наприклад, Національний банк України);

- регулювання цін на ресурси та послуги.

Національний банк України може претендувати на роль мегарегулятора інформаційно-кредитного ринку виходячи з таких міркувань.

По-перше, Національний банк України має у своєму розпорядженні потужні інформаційні системи, які дають змогу акумулювати великий обсяг інформації. Ілюстрацією може служити зростання кількості титульних частин кредитних історій, накопичених у базі даних Єдиного реєстру бюро кредитних історій (рис. 2), а також розвиток інформаційно-телекомунікаційної системи Національного банку України і високий рівень захищеності інформації [5].

По-друге, Національний банк України має у своєму розпорядженні професійно підготовлених, зі стабільним колективом кваліфікованих співробітників. Інформаційні послуги в банківській сфері відносяться до інтелектуальних фінансових послуг, регулювання яких також має перебувати на адекватному рівні.

Істотна частина працівників Центрального апарату Національного банку України $(58,4 \%)$ має досвід роботи в банківській системі не менше трьох років і $33,6 \%$ - 15 років і більше, зберігається тенденція до збільшення кількості керівників і фахівців із вищою професійною освітою. Станом на 01.01.2020 частка таких фахівців становила 78\% [3].

По-третє, Національний банк України не є учасником конкуренції на інформаційно-кредитному ринку і не використовуватиме наявну інформацію в меркантильних цілях [4, с. 185].

I головне - як регулятор банківської системи Національний банк України має у своїх руках додаткові 


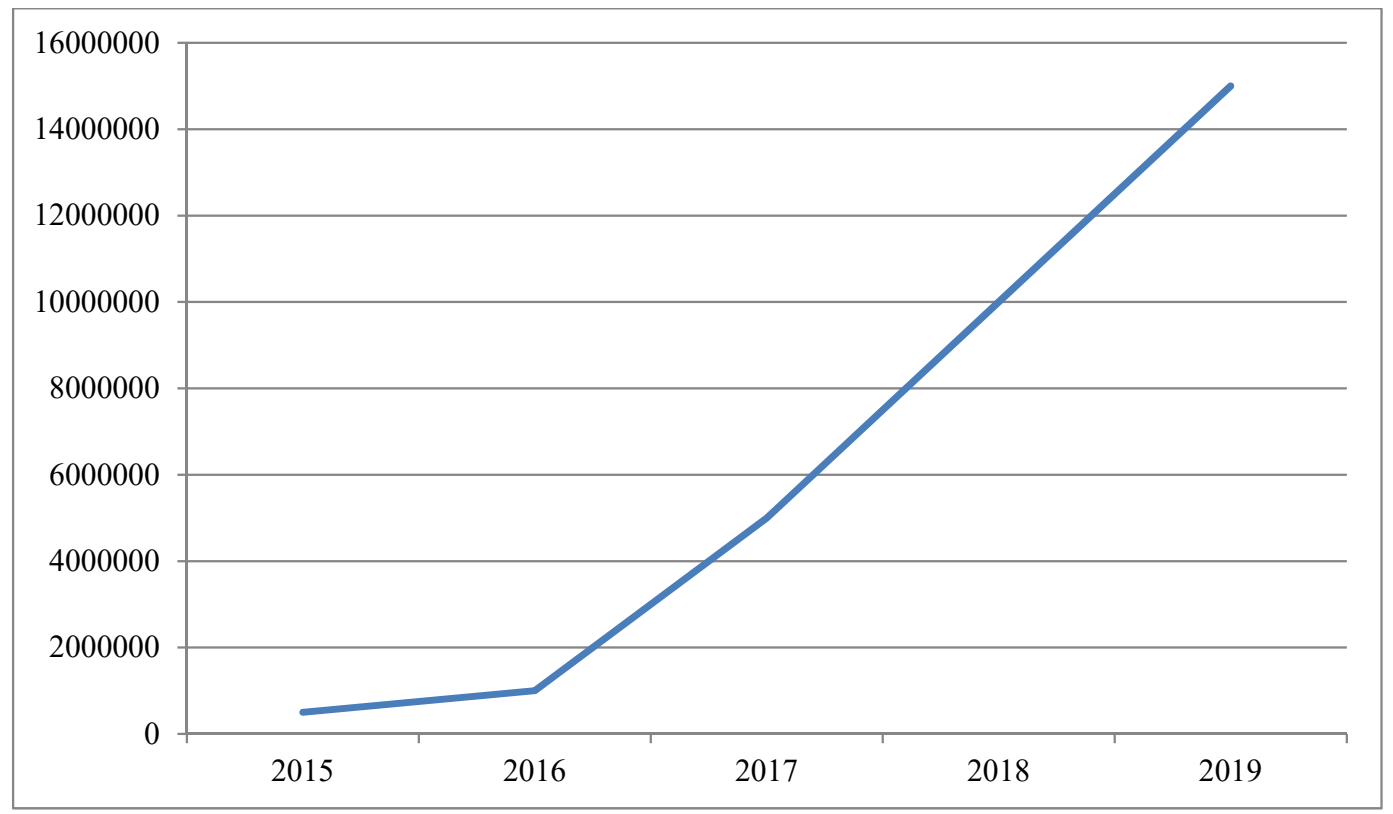

Рисунок 2 - Наповнення бази даних Сдиного ресстру бюро кредитних історій

(прямі і непрямі) важелі впливу на основних постачальників кредитної інформації.

Висновки. Для подальшого розвитку ринку кредитних послуг в Україні в умовах євроінтеграції потрібна нова інформаційна структура зі спрощеним доступом до інформації різних відомств. При цьому важлива координація у створенні і порядку доступу до інформації, дослідженні реальних інформаційних потреб. Такою інформаційною структурою може стати інформаційнокредитний ринок. Координувати (регулювати) роботу учасників інформаційно-кредитного ринку повинен мегарегулятор. Це пов'язано з тим, що учасники являють собою різні групи, регульовані різними органами; структура учасників складна і прагне до універсалізації. Водночас в кожній із груп є учасник, діяльність якого регулюється тільки Національним банком України.

\section{Список використаних джерел:}

1. Вовчак О.Д. Кредит і банківська справа : підручник. Київ : Знання, 2008. 564 с.

2. Вядрова Н.Г., Подорожна А.М., Якуценя Л.А. Сучасні моделі фінансового супермаркету в Україні. Фінансово-кредитна діяльність: проблеми теорії та практики. 2016. Вип. 2. № 21. С. 55-67.

3. Сдиний реєстр бюро кредитних історій. Нацкомфінпослуг : вебсайт. URL: https://www.nfp.gov.ua/ua/Yedynyi-reiestrbiuro-kredytnykh-istorii.html.

4. Коваленко В.В. Регулювання та нагляд за кредитними установами. Держава та регіони. Серія «Економіка та підприємниитво. 2018. № 4(108). С. 185-192.

5. Миськів Г.В. Проблема визначення об'єкту кредитного ринку. Вісник Одеського національного університету. Серія «Економіка». 2013. Вип. 2/1. С. 41-44.

6. Про організацію формування та обігу кредитних історій : Закон України від 23 червня 2005 р. № 2704-IV. Bidoмості Верховної Ради України. 2005. № 32. Ст. 421.

7. Про фінансові послуги та державне регулювання ринків фінансових послуг : Закон України від 12.07.2001 № 2664-III. URL: http: zakon4.rada.gov.ua/laws/show/2664-14.

\section{References:}

1. Vovchak O.D. (2008) Kredyt i bankavska sprava [credit and banking]. Kyiv: Znannya. (in Ukrainian)

2. Viadrova N.G., Podorozhna A.M., Yakutsenya L.A. (2016) Suchasni modeli finansovogo supermarket v Ukrayini [Modern models of financial supermarket in Ukraine]. Collection of scientific works "Financial and credit activities: problems of theory and practice", vol. 2, no. 21, pp. 55-67.

3. Natzkomfinposlug. Yedynyy reyestr byuro kredytnuh istoriy [Unified register of credit bureaus]. Available at: https://www.nfp.gov.ua/ua/Yedynyi-reiestr-biuro-kredytnykh-istorii.html.

4. Kovalenko V. V. (2018) Regulyuvannya ta naglyad za kredytnymy ustanovamy [Regulation and supervision of credit institutions]. State and regions. Series "Economics and Entrepreneurship, vol. 108, no. 4, pp. 185-192.

5. Myskiv G.V. (2013) Problema vyznachennya obyektu rynku [The problem of determining the object of the credit market]. Bulletin of Odessa National University. Series: Economics, vol. 2, no. 1, pp. 41-44.

6. Law of Ukraine on the organization of the formation and circulation of credit histories № 2704-IV (2005 june 23). Vidomosti Verkhovnoyi Rady Ukrayiny, no. 32, st. 421. (in Ukrainian)

7. Law of Ukraine on financial services and state regulation of financial services markets № 2664-III (2001 july 12). Available at: http: zakon4.rada.gov.ua/laws/show/2664-14. 
Kalyta Oksana, Sunduk Tetyana

Kyiv National University of Trade and Economics

\section{STRATEGIC DIRECTIONS OF REFORMING THE MARKET OF CREDIT SERVICES IN UKRAINE IN THE CONTEXT OF EUROPEAN INTEGRATION PROCESSES}

The article examines the theoretical foundations and provides practical recommendations for the introduction, formation and development of the information and credit market of Ukraine. The purpose of writing this article is to develop theoretical and methodological foundations, scientific and methodological approaches and practical recommendations for reforming the credit services market in Ukraine in the context of European integration. This paper uses a set of methods of scientific cognition, which ensured the conceptual unity and relevance of the study. The methodological basis of the study is a systemic and institutional approaches, according to which the information and credit market is considered in close connection with the implementation of objective laws and institutional features, both its market organization and government regulation. The essence of the definition of "information and credit market" is revealed, by which we understand the specific economic relations between owners and users of information resources and services that mediate their exchange, purchase and sale within the credit system of Ukraine. The end product of the information and credit market is an information resource or service that is offered as a commodity, in order to ensure monetary relations of participants in the credit services market. The specificity of this product is that its significant part has only consumer value and is sold free of charge. The article reveals that for the qualitative development of the information and credit market it is necessary to form a professional regulatory system, a control mechanism, as well as objective supervision (supervisory body). The article proves that the lack of a single licensing and management body operating under standard rules can lead to increased costs for government regulators in reforming the credit services market in Ukraine. It is concluded that the development of the credit services market in Ukraine in the context of European integration requires a new information structure with simplified access to information from various departments.

Key words: credit services, information and credit market, credit histories bureau, credit market subjects, National Bank of Ukraine.

JEL classification: G10, G21, E51 